\title{
A Novel Spore Collection Device for Sampling Exposure Pathways: A Case Study of Puccinia psidii
}

J. L. Holliday and S. A. Jones, Australian Centre of Excellence for Risk Analysis, School of Botany, University of Melbourne, Parkville, Victoria 3010, Australia; J. A. Simpson, Department of Agriculture, Fisheries and Forestry, Canberra, ACT 2601, Australia; M. Glen, Tasmanian Institute of Agriculture, University of Tasmania, Hobart, Tasmania 7001, Australia; J. Edwards, Department of Primary Industries, Knoxfield, Victoria 3180, Australia; A. Robinson, Australian Centre of Excellence for Risk Analysis, School of Botany, and Department of Mathematics and Statistics, University of Melbourne; and M. A. Burgman, Australian Centre of Excellence for Risk Analysis, School of Botany, University of Melbourne

\begin{abstract}
Holliday, J. L., Jones, S. A., Simpson, J. A., Glen, M., Edwards, J., Robinson, A., and Burgman, M. A. 2013. A novel spore collection device for sampling exposure pathways: A case study of Puccinia psidii. Plant Dis. 97:828-834.

A device comprising a filter attached to a vacuum cleaner was purposebuilt to sample rust spores from three potentially high-risk pathways in Australia: passengers, fresh flowers, and sea cargo. The proportion of spores recovered from eight surfaces comparable with those on each pathway (cotton, denim, roses, carnations, chrysanthemums, wood, plastic, and metal) was estimated in the laboratory. Spore recovery percentages were highest for denim clothing (61\% Puccinia triticina Erikss. and $62 \%$ Uromycladium tepperianum) and lowest for carnations (4\% P. triticina Erikss. and 5\% U. tepperianum). Subsequently, the device was tested at several locations on the Central Coast of New South Wales, Australia, recently affected by a "myrtle rust" outbreak. Symptomatic and asymptomatic myrtle rust hosts, myrtle rust nonhosts, and inanimate objects (e.g., clothing and vehicles) were sampled

in conjunction with the emergency response to the outbreak. A polymerase chain reaction (PCR) assay developed for $P$. psidii established the presence of myrtle rust, and visual inspections provided spore count estimations. All samples from symptomatic myrtle rust hosts produced positive PCR results and spore count estimations were generally much greater. Several samples from asymptomatic myrtle rust hosts, myrtle rust nonhosts, and inanimate objects also produced positive PCR results; however, there were discrepancies between PCR results and spore count estimations in some of these samples, all of which had $<100$ spores. This study highlights the utility of the device and analytical methodology, especially during the early stages of a disease outbreak when infection symptoms on plants and contamination on objects is not visible upon gross examination.
\end{abstract}

Australia is in a unique position with respect to biosecurity because of its remoteness, unique biodiversity, low-density population, and relatively recent settlement by Europeans. Strict quarantine measures have been effective in protecting Australian agriculture, horticulture, and forestry from many pests and diseases that affect trading partners and competitors (23). Recent changes to open up and promote world trade, combined with an increase in the volumes and speed of international tourism, are now increasing the challenges to quarantine and biosecurity $(1,8,28,34)$. The Beale Review of Australia's biosecurity system recommended that riskprofiling methods should focus on risk-return profile analysis (1). Accordingly, the Department of Agriculture, Fisheries and Forestry, in collaboration with the Australian Centre of Excellence for Risk Analysis, initiated a research project to develop a risk analysis framework for pests and pathogens that have multiple pathways for entry into Australia. Specifically, the project explored the use of pathway modeling and spatial habitat analyses to evaluate the risks of entry, establishment, and spread of a group of closely related fungal pathogens with broad host ranges and with hypothesized multiple entry pathways. As a case study, the project focused on multiple exposure pathways for

Corresponding author: J. L. Holliday, E-mail: taylorj@unimelb.edu.au

Current address of J. A. Simpson: 15 Sprent St., Narrabundah, ACT 2604, Australia.

* The $e$-Xtra logo stands for "electronic extra" and indicates that Figures 1, 2,4 , and 5 appear in color online.

Accepted for publication 12 January 2013.

http://dx.doi.org/10.1094/PDIS-06-12-0565-RE

(c) 2013 The American Phytopathological Society pathogens in the Puccinia psidii sensu lato complex, guava rust, into Australia.

The pathogens in the $P$. psidii sensu lato complex (hereafter $P$. psidii) cause a disease variously known as guava rust, eucalyptus rust, 'ohi'a rust, and myrtle rust which typically affects young, actively growing tissues in susceptible hosts within the family Myrtaceae $(6,21,32)$. Symptoms of the disease typically include leaf lesions, leaf and shoot distortion, and shoot dieback following the emergence of uredinia that produce yellow masses of urediniospores. In severe outbreaks, extensive defoliation, flower blight, fruit infection, and dieback can manifest in young trees of highly susceptible species $(9,32)$.

Guava rust is native to South and Central America, where it was first described on guava (Psidium guajava) in Brazil in 1884 (38). Subsequent to the first record on guava, the reported host range of guava rust has extended and presently includes 129 species in 33 genera, all in the Myrtaceae family (5). The geographic range of guava rust has also expanded to include North America (Mexico and the United States, including Hawaii), most countries of South America, the Caribbean, and, more recently, Japan and China $(12,25,31,32,39)$.

Quarantine measures have been in place in Australia since the mid-1980s to minimize risk of introduction of guava rust, which could cause major damage to host plant populations, because members of the Myrtaceae family dominate many natural plant communities in Australia and include plants that sustain economically important industries $(12,13)$. However, with increasing volumes and speed of international trade and tourism, and with the pathogen moving geographically closer to Australia in recent years, there had been increasing concern about the potential of an incursion to Australia. In April 2010, this potential was realized when an outbreak of an exotic rust that resembled $P$. psidii was detected on the Central Coast of New South Wales (NSW), Australia (6). The fungus was identified as Uredo rangelii, an anamorph species in the 
guava rust complex, based on urediniospore morphology $(6,31)$ and given the common name "myrtle rust". However, it is now believed that the Australian rust is a strain of Puccinia psidii based on observations of teliospores that match the description of $P$. psidii sensu stricto $(4,5)$.

Like many exotic rust incursions, it is unclear when and where P. psidii entered Australia (3). In 2004, the Australia Quarantine and Inspection Service detected spores resembling $P$. psidii on sawn Eucalyptus timber imports from Brazil, including the plastic wrapping and the external surfaces of shipping containers. Molecular analyses confirmed that the fungus was $P$. psidii, and viability testing confirmed that the spores were viable after the 2-month journey at sea (13). Although trade in timber of Eucalyptus spp. from countries where guava rust is established was suspended in response to this detection, the finding suggests that the external surfaces of shipping containers and their contents (whether timber or other commodities) can become contaminated by airborne spores if the port of origin is located in close proximity to areas where guava rust is established (13).

Humans can also transport rust fungi, either deliberately or inadvertently (36). Spores adhering to clothing and personal effects of passengers arriving from countries where the pathogen is established is a known mode of introduction $(29,33,35,36)$. In the early $1980 \mathrm{~s}$, Sheridan detected approximately 70,000 viable rust urediniospores of diverse species present on clothing and baggage of Australian passengers arriving into Wellington airport, New Zealand (29). Furthermore, Wellings et al. (36) investigated the viability of $P$. striiformis f. sp. tritici urediniospores present on clothing. Contaminated clothing was stored at room temperature for 1 week before being shaken over susceptible seedlings. After 2 weeks, seedlings were heavily infected with uredinia and sporulation was abundant. To minimize the risk of pathogen introductions via this pathway, they recommended washing clothing and personal effects suspected of being contaminated. However, a study by Sheridan and Nendick (30) found that one machine wash of contaminated clothing removed only half of the spores present, and many may have remained viable after washing.

This study describes the design and testing of a collection device for rust spores that was developed to sample three potentially highrisk, border-crossing pathways relevant to guava rust: passengers arriving by air, fresh cut flowers arriving as air cargo, and sea cargo. To extract spores from commodities and surfaces on the putative pathways, a device comprising an open-face filter housing connected to a hand-held vacuum cleaner was purpose-built, and was tested in the laboratory and the field to establish its utility as a spore collection tool. The outcomes of these experiments are reported here. Possible applications of the device in wider contexts and recommendations for further experimentation are discussed.

\section{Materials and Methods}

Spore collection device and components. A hand-held and fully portable Dyson DC31 vacuum cleaner (model number DC31DMMHSP; Dyson Appliances Limited), measuring 320 by

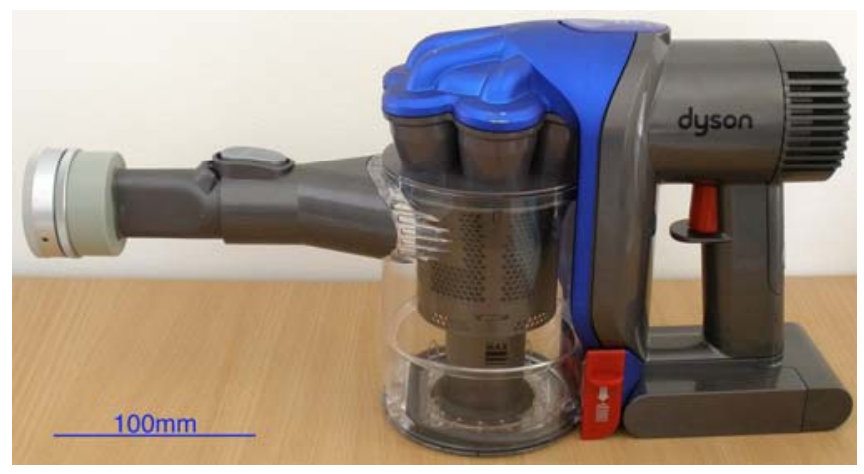

Fig. 1. Spore collection device comprising a modified filter housing connected to a Dyson DC31 vacuum cleaner.
110 by $200 \mathrm{~mm}$, was modified to function as a spore collection device (Fig. 1). A 47-mm-diameter circular aluminum open-face filter housing (Pall Life Sciences, Pall Corporation) was adapted to screw on to the original hose that connects to the vacuum outlet via a threaded plastic block that was permanently fixed to the hose (Fig. 2).

Single 5- $\mu \mathrm{m}$ pore-size, 47-mm-diameter PVC filter membranes (Pall Life Sciences, Pall Corporation) were placed in the filter housing and used to trap spores and debris. A permeable stainlesssteel mesh screen covering a 3-mm-pore-size stainless steel backing plate supported the filter membrane during vacuuming. An o-ring (Viton) was locked around the outer $6 \mathrm{~mm}$ of the filter membrane to fasten it during vacuuming, leaving a total area of $9.6 \mathrm{~cm}^{2}$ available to trap spores and debris. All components of the filter housing were periodically removed (by unscrewing it from the plastic block permanently fixed to the hose) for steam sterilization in an autoclave at 121 to $123^{\circ} \mathrm{C}\left(250\right.$ to $\left.253^{\circ} \mathrm{F}\right)$ and 1.0 bar $(100$ $\mathrm{kPa}, 15 \mathrm{psi}$ ) for 15 to $20 \mathrm{~min}$.

A digital motor powered the vacuum and centrifugal forces spun dirt and debris at an airflow rate of 24.4 CFM and a velocity of 12 $\mathrm{m} / \mathrm{s}$. The vacuum's standard power mode delivered continuous suction for $15 \mathrm{~min}$, corresponding to a suction power of $337 \mathrm{~mm}$ $\mathrm{H}_{2} \mathrm{O}$.

Laboratory experiments. Laboratory testing commenced in July 2010. Eight surface types comparable with those on the target pathways were tested: cotton and denim (passenger pathway); roses, carnations, and chrysanthemums (fresh cut flower pathway); and wood, plastic, and metal (sea cargo pathway). Each "surface" was defined as a pair of jeans (denim); a t-shirt (cotton); a 10-stem bunch each of roses, carnations, and chrysanthemums (wrapped in paper or plastic); and a single 50-by-50-cm sheet of wood (roughsawn treated pine), plastic (flexible PVC), and metal (stainless steel).

Plant material. Quarantine restrictions in Australia precluded use of $P$. psidii urediniospores in the laboratory experiments. Uromycladium tepperianum (Sacc.) McApline and P. triticina Erikss., two common species of rust fungi in Australia, were used as model pathogens because they are pervasive in Australia and their spore morphologies are similar to urediniospores of $P$. psidii $(10,14,15)$.

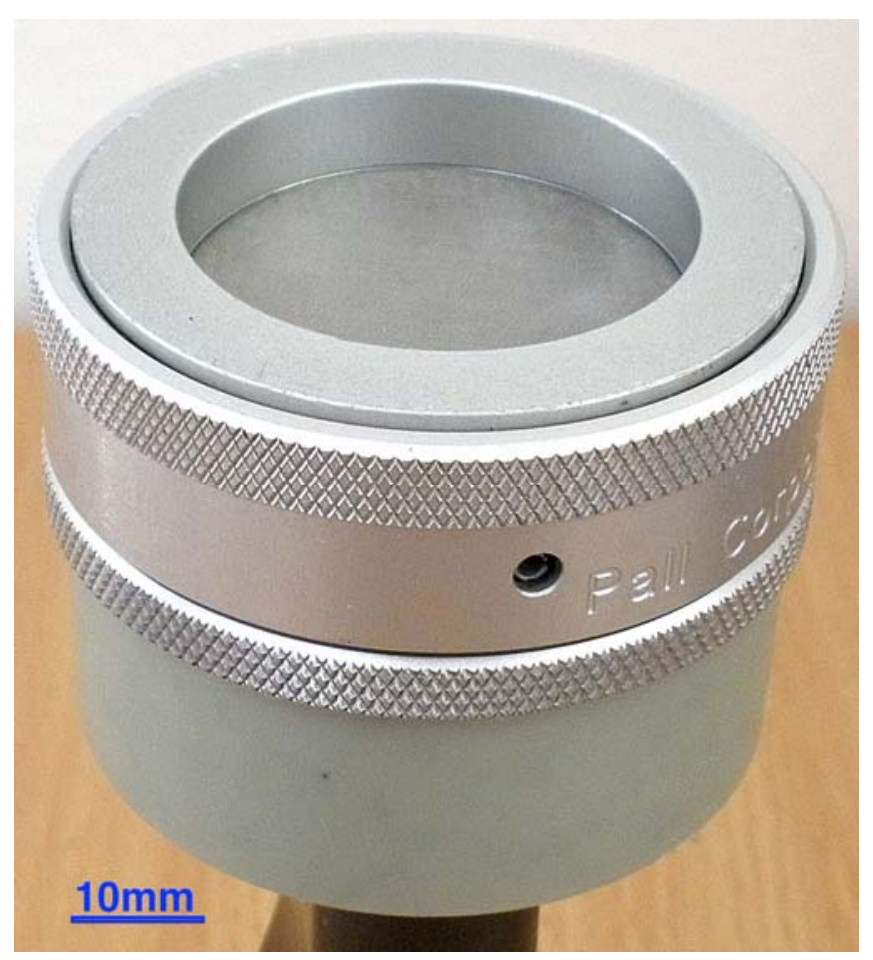

Fig. 2. Detachable filter housing that connects to the vacuum and traps spores and debris during vacuuming. 
Teliospores of the Acacia gall rust fungus, U. tepperianum, were harvested from a diseased Acacia saligna tree located at the far northeastern corner of the Murdoch University campus (Western Australia, Australia). Heavily affected sections were cut and teliospores were harvested from the galls by scraping the surface with a clean scalpel. The spores were air dried at room temperature for 24 $\mathrm{h}$ and stored in 1.7-ml microcentrifuge tubes (Axygen Incorporated). Urediniospores of the wheat leaf rust pathogen, $P$. triticina Erikss., were harvested and supplied by the Western Australian Department of Agriculture and Food.

Inoculation protocol. Surfaces were inoculated by spraying spores using a Preval Sprayer Unit (Precision Valve Corporation) that comprised an atomizer attached to a glass reservoir. This application method is widely reported in other similar contexts $(7,22,24)$ and allowed spores to disperse and lightly adhere to the surfaces, thereby mimicking natural dispersal mechanisms.

One Preval Sprayer Unit was used for each species' suspension and each was prepared by vortexing $1 \mathrm{mg}$ of spores in $100 \mathrm{ml}$ of deionized water for approximately $30 \mathrm{~min}$. The concentration of spores in each suspension was standardized at 1,000 spores $\mathrm{ml}^{-1}$, which was verified by spraying three replicate PVC filter membranes with $1 \mathrm{ml}$ of suspension at a distance of $50 \mathrm{~mm}$ and counting the number of spores present within the entire area of the filter membrane using a dissecting microscope ( $\times 70$ magnification). (The diameter of the spray "fan" was approximately the same diameter as the filter membrane at a distance of $50 \mathrm{~mm}$; hence, all spores sprayed at this distance landed within the filter membrane.) The mean spore count across the three replicates for each suspension was used in the subsequent spore recovery calculation.

The eight surface types were prepared for each model pathogen. Each surface was partitioned into three discrete areas to give three replicates per surface, with the exception of the flowers, where a 10 -stem bunch wrapped in paper or plastic was one replicate. Each replicate was directly sprayed with $1 \mathrm{ml}$ of suspension at a distance of $50 \mathrm{~mm}$ (as described above). Due to the structural complexity of the flowers, and to ensure that all spores sprayed onto the flowers actually landed within the bunch, each flower bunch was unwrapped and the individual flowers laid out in a uniform layer on their paper or plastic wrapping prior to inoculation.

Quantifying spore recovery. Once dry, each replicate of each surface, including all parts of the flowers and their wrapping, was vacuumed for $30 \mathrm{~s}$ using a single filter membrane. This length of time was anticipated as the maximum allowable time to sample passengers (the most time-sensitive pathway) in the pathway sampling. Between each replicate, the filter housing and tools (e.g., tweezers) were thoroughly cleaned with alcohol swabs (MediSwabs, saturated with $70 \%$ [vol/vol] isopropyl alcohol) to minimize the risk of cross-contamination. Using a dissecting microscope ( $\times 70$ magnification), the number of spores present within the entire area of each filter membrane was counted. The number of spores recovered from each replicate was calculated as a percentage of the suspensions' mean spore counts.

Field experiments. Field testing commenced in September 2010 and was carried out in collaboration with the NSW state government which, at the time, was implementing surveillance, tracing, quarantine, and destruction activities as part of the emergency response to an outbreak of "myrtle rust" on the Central Coast of NSW, Australia (3).

Sampling protocol. The selection of sites, or infected premises (IPs), for sampling was based largely upon accessibility and the number of symptomatic myrtle rust host plants detected at each IP. The numbers and types of samples collected at each IP could not be predetermined because the exact nature of the IPs (i.e., the number of symptomatic and asymptomatic myrtle rust host plants) was unknown prior to arrival. The objective was to take samples directly from myrtle rust host plants with visible symptoms of disease (e.g., leaf and shoot lesions that, when young, are distinct yellow spots). Myrtle rust host plants with no visible symptoms of disease (i.e., either healthy or diseased but undetectable), myrtle rust nonhost plants, and inanimate objects (e.g., clothing and vehicles of surveillance personnel, and objects located within IPs) located in close proximity to symptomatic myrtle rust host plants were also sampled. Details of each IP targeted, including the number of symptomatic myrtle rust host plants detected and the number of samples collected at each, are shown in Table 1.

The accessible leaves, shoots, and (where applicable) fruit of target plants were vacuumed, with particular focus on the sporulating uredinial pustules that are present on young, actively growing leaves and shoots of susceptible myrtle rust host plants. For the inanimate objects, all accessible areas were vacuumed (where the objects were too large to be vacuumed entirely, representative areas were vacuumed). Samples were collected in batches at each IP to minimize the risk of cross-contamination. That is, symptomatic myrtle rust host plants were sampled in one batch and asymptomatic myrtle rust host plants, myrtle rust nonhost plants, and inanimate objects were sampled in another batch. In addition, the sampler wore gloves and thoroughly cleaned the vacuum, filter housing, and tools with alcohol swabs between each sample. A single filter membrane was used for each plant or inanimate object, and each was stored in individual paper envelopes.

Sample handling and analysis. Samples were gamma irradiated at $25 \mathrm{kGray}$ and packaged according to state biosecurity procedures before they were dispatched to a laboratory in Tasmania, Australia, for analysis. Each filter membrane was cut into one half and two quarters. One arbitrarily selected quarter was analyzed for the presence of $P$. psidii using a DNA extraction protocol followed by a nested polymerase chain reaction (PCR) assay developed for P. psidii (20), which also detects the Australian strain (6). The DNA extraction protocol was adapted to accommodate the filter membrane samples, and an initial amplification of the ribosomal DNA internal transcribed spacer (ITS) region using the fungal-specific primers ITS1-F (11) and ITS4 (37) was carried out before the specific assay in order to enhance the sensitivity to within the detection thresholds reported in the original publication (M. Glen, unpublished).

To estimate the numbers of spores present in each sample, and as a basic crosscheck for potential false negatives from the PCR tests, another quarter of each sample was systematically visually inspected using a dissecting microscope ( $\times 70$ magnification). Each filter membrane was stained with Melzer's reagent to highlight fungal material. Many samples, particularly those from symptomatic myrtle rust host plants, were expected to contain large numbers of $P$. psidii spores. For these samples, a wedge approximately one-fifth the size of the filter membrane quarter was cut and the number of spores present on the wedge was estimated by visually scanning the entire area of the wedge. The count estimation was multiplied by five and categorized as follows: A, 0 spores; $\mathrm{B}, \geq 1$ but $<20$ spores; C, $>20$ but $<100$ spores; D, $>100$ but $<500$ spores; E, $>500$ but $<2,000$ spores; and $\mathrm{F},>2,000$ spores.

Table 1. Details of the infected premises sampled during the field experiments

\begin{tabular}{ll}
\hline Type of infected premises & Number of symptomatic myrtle rust host plants detected (at the time of sampling) \\
\hline Nursery 1 & Approximately 10 Gossia inophloia (syn. Austromyrtus inophloia) potted juvenile plants \\
Private residence & 1 native Syzygium jambos tree (approximately $2 \mathrm{~m}$ tall) \\
Commercial cut-flower property & $>1,000$ Agonis flexuosa 'Afterdark' plants and several native plants within and immediately \\
& surrounding the property, including Syncarpia glomulifera (windbreak) trees \\
Nursery 2 & $>300$ G. inophloia (syn. A. inophloia) potted juvenile plants \\
State institution & 4 native Rhodamnia rubescens trees (approximately $6-8 \mathrm{~m}$ tall) \\
\hline
\end{tabular}




\section{Results}

Laboratory experiments. The mean spore counts in the suspensions were 1,068 spores $\mathrm{ml}^{-1}$ (standard deviation $[\mathrm{SD}] \pm 72, n=3$ ) for $U$. tepperianum and 1,113 spores $\mathrm{ml}^{-1}(\mathrm{SD} \pm 122, n=3)$ for $P$. triticina. Consistently similar spore counts between replicates were observed for several batches of suspensions that were prepared over the course of the laboratory experiments (data not shown).

The highest percentage of spores was recovered from denim clothing for $U$. tepperianum (mean $=62 \%, \mathrm{SD} \pm 8.4, n=3$ ) and $P$. triticina $($ mean $=61 \%, \mathrm{SD} \pm 7.2, n=3)$ (Fig. 3). The percentage of spores recovered form the hard surfaces (i.e., wood, plastic, and metal) and all three kinds of flowers was comparatively lower for both species. There was no significant difference in spore recovery percentages between species for the various surfaces, with the exception of the wood surface, where $P$. triticina had a significantly $(P=0.03)$ higher percentage recovery (Fig. 3$)$.

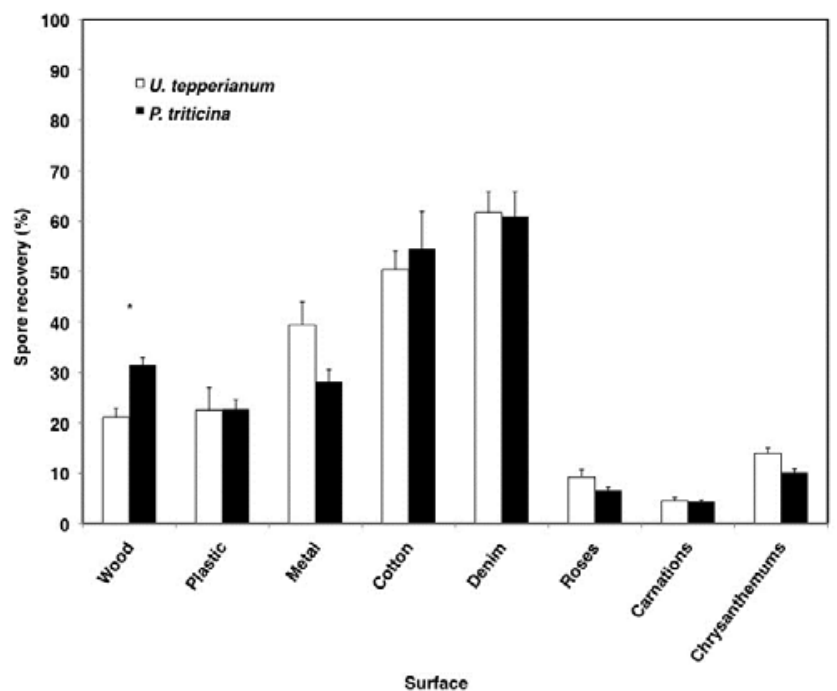

Fig. 3. Percentage of Uromycladium tepperianum (white) and Puccinia triticina Erikss. (black) spores recovered from each of the eight different surfaces. Error bars are standard errors of the means and the asterisk denotes a statistically significant difference $(P=0.03)$.
Field experiments. In total, 60 samples were collected across the five IPs; 21 of these were from symptomatic myrtle rust host plants (Table 2). Field observations indicated that many of these samples had thousands of $P$. psidii spores because the (white) filter membranes were distinctly yellow after vacuuming just a few sori. All of these samples produced positive PCR results, with the exception of three that remain unknown because they were inadvertently destroyed during the DNA extraction process. Furthermore, visual inspections confirmed the presence of thousands of urediniospores in many of these samples (Table 2; Fig. 4). They also revealed the distribution of spores on the filter membrane, which was useful when deciding on how to section each for analyses. Spores (and debris) collected during vacuuming were most densely deposited around the outer perimeter of the filter membrane where the oring was positioned, creating a discernible ring (Fig. 5).

Positive PCR results were also produced for five samples from asymptomatic myrtle rust host plants (sample IDs 007, 008, 011, 013, and 014), one sample from a myrtle rust nonhost plant (sample ID 054), and one sample from a 6-week-old mulch heap of Syncarpia glomulifera and Agonis flexuosa 'Afterdark' (sample ID

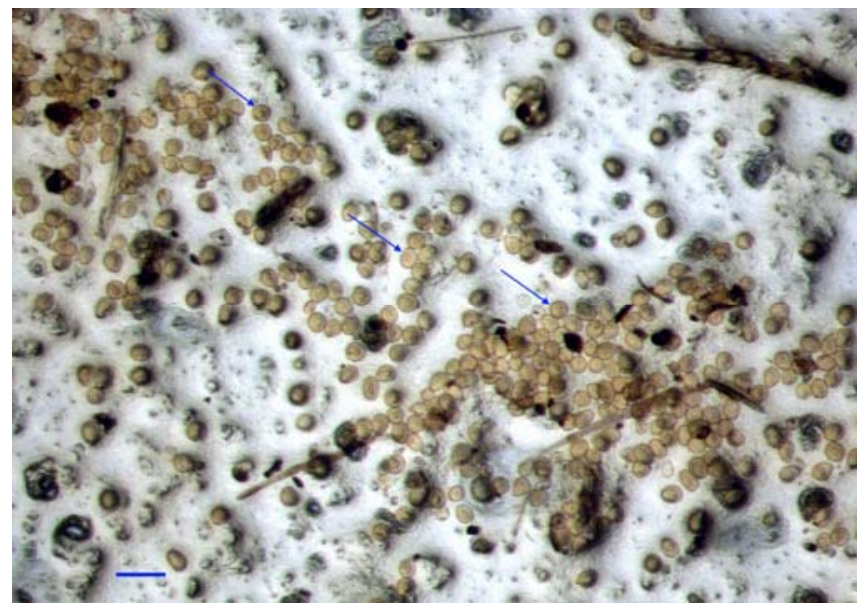

Fig. 4. Masses of Puccinia psidii urediniospores (arrows) vacuumed from the leaves and shoots of Gossia inophloia (syn. Austromyrtus inophloia) (sample ID 021). $\mathrm{Bar}=0.1 \mathrm{~mm}$.

Table 2. Details of each sample collected from symptomatic myrtle rust host plants, including the results of spore count estimates and polymerase chain reaction $(\mathrm{PCR})$ tests

\begin{tabular}{|c|c|c|c|c|}
\hline Sample ID & Type of infected premises & Description of sample ${ }^{x}$ & Spore count estimate ${ }^{y}$ & PCR result ${ }^{\mathrm{z}}$ \\
\hline 001 & Nursery 1 & Leaves and shoots of Gossia inophloia & $\mathrm{D}$ & Positive \\
\hline 002 & Nursery 1 & Leaves and shoots of $G$. inophloia & $\mathrm{D}$ & Positive \\
\hline 003 & Nursery 1 & Leaves and shoots of G. inophloia & $\mathrm{E}$ & Positive \\
\hline 004 & Nursery 1 & Leaves and shoots of $G$. inophloia & $\mathrm{E}$ & Positive \\
\hline 005 & Nursery 1 & Leaves and shoots of G. inophloia & $\mathrm{D}$ & Positive \\
\hline 006 & Nursery 1 & Leaves and shoots of G. inophloia & $\mathrm{D}$ & Positive \\
\hline 010 & Nursery 1 & Leaves and shoots of G. inophloia & $\mathrm{C}$ & Unknown \\
\hline 021 & Nursery 2 & Leaves and shoots of G. inophloia & $\mathrm{F}$ & Positive \\
\hline 022 & Nursery 2 & Leaves and shoots of $G$. inophloia & E & Positive \\
\hline 023 & Nursery 2 & Leaves and shoots of G. inophloia & $\mathrm{F}$ & Unknown \\
\hline 024 & Nursery 2 & Leaves and shoots of G. inophloia & E & Positive \\
\hline 025 & Nursery 2 & Leaves and shoots of G. inophloia & $\mathrm{F}$ & Positive \\
\hline 026 & Nursery 2 & Leaves and shoots of G. inophloia & $\mathrm{C}$ & Positive \\
\hline 027 & Nursery 2 & Leaves and shoots of G. inophloia & B & Positive \\
\hline 028 & Nursery 2 & Leaves and shoots of G. inophloia & B & Positive \\
\hline 029 & Nursery 2 & Leaves and shoots of G. inophloia & $\mathrm{C}$ & Positive \\
\hline 030 & Nursery 2 & Leaves and shoots of G. inophloia & $\mathrm{B}$ & Unknown \\
\hline 044 & State institution & Leaves, shoots, and fruit of Rhodamnia rubescens & $\mathrm{F}$ & Positive \\
\hline 045 & State institution & Leaves, shoots, and fruit of $R$. rubescens & $\mathrm{E}$ & Positive \\
\hline 046 & State institution & Leaves, shoots, and fruit of $R$. rubescens & $\mathrm{F}$ & Positive \\
\hline 047 & State institution & Leaves, shoots, and fruit of $R$. rubescens & $\mathrm{D}$ & Positive \\
\hline
\end{tabular}

${ }^{\mathrm{x}}$ Spore count estimates: A, 0 spores; $\mathrm{B}, \geq 1$ but $<20$ spores; $\mathrm{C},>20$ but $<100$ spores; $\mathrm{D},>100$ but $<500$ spores; E, $>500$ but $<2,000$ spores; and F, $>2,000$ spores.

y Gossia inophloia (syn. Austromyrtus inophloia).

${ }^{\mathrm{z}}$ Unknown $=$ samples were inadvertently destroyed during the DNA extraction process. 
018) (Table 3). All of these samples were either adjacent to or within a few meters of symptomatic myrtle rust host plants, with the exception of the last sample (sample ID 018), where all remaining myrtle rust host plants on the premises had been removed and destroyed during the 3 months preceding the field experiments. Up to 100 spores were observed in most of these samples; however, no spores were observed in one of the samples from an asymptomatic

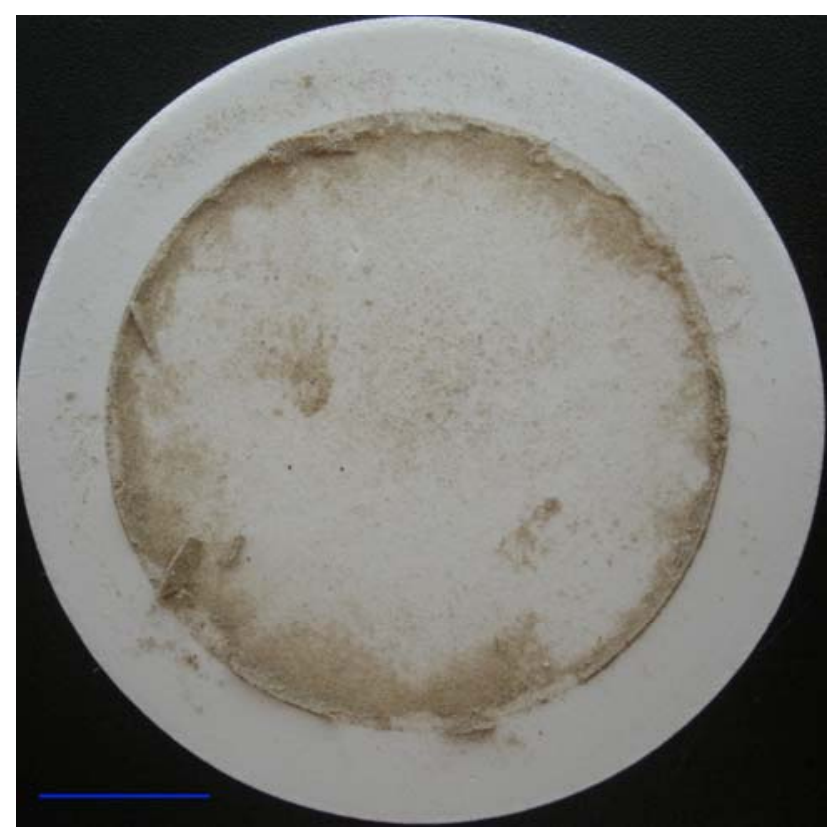

Fig. 5. Sample from the outer surface of clothing worn underneath disposable overalls by surveillance personnel during inspections at an infected premises on the Central Coast of New South Wales, Australia (sample ID 043). Bar $=10 \mathrm{~mm}$. myrtle rust host plant (sample ID 014) and the sample from the 6week-old mulch heap (sample ID 018) that was visibly contaminated with soil (Table 3).

More surprisingly, positive PCR results were produced for four samples from inanimate objects: one sample from clothing worn underneath disposable overalls worn onsite (sample ID 019), two samples from the outer surface of disposable overalls worn onsite (sample IDs 041 and 042), and one sample from the wheel of a vehicle parked near symptomatic myrtle rust host plants (sample ID 058) (Table 4). These samples were in close proximity to symptomatic myrtle rust host plants, with the exception of the clothing worn underneath the overalls (sample ID 019), which was always covered by the full-body-length overalls worn onsite by surveillance personnel. Up to 100 spores were observed in the two samples from the outer surface of disposable overalls (sample IDs 041 and 042); however, no spores were observed in the dirtier samples from clothing worn underneath disposable overalls (sample ID 019) and the wheel of a vehicle (sample ID 058) (Table 4).

\section{Discussion}

Although there are many examples of commercially available sampling devices for the collection of fungal plant pathogens, their size and functionality are such that it was not feasible to collect samples from pathway surfaces and commodities. This led to the development of a novel spore collection device for our particular application, and we found several examples in the literature of purpose-built vacuum devices for rust spore sampling $(27,30)$. To be effective, the device had to recover spores from a range of surfaces and, for operational reasons, it also had to be portable, be able to be cleaned between samples to minimize cross-contamination, and use sample media suitable for molecular analyses.

The device was evaluated in the laboratory and the field to establish its usefulness as a spore collection tool. In the laboratory, spore recovery percentages were highest for the pliable clothing compared with the rigid surfaces and structurally complex flowers

Table 3. Details of each sample collected from asymptomatic myrtle rust host and myrtle rust nonhost plants located near symptomatic myrtle rust host plants, including the results of spore count estimates and polymerase chain reaction (PCR) tests

\begin{tabular}{|c|c|c|c|c|}
\hline Sample ID & Type of infected premises & Description of samplew & Spore count estimate ${ }^{x}$ & PCR result ${ }^{y}$ \\
\hline 007 & Nursery 1 & Leaves and shoots of Gossia inophloia & $\mathrm{C}$ & Positive \\
\hline 008 & Nursery 1 & Leaves and shoots of G. inophloia & $\mathrm{C}$ & Positive \\
\hline 009 & Nursery 1 & Leaves and shoots of G. inophloia & $\mathrm{C}$ & Unknown \\
\hline 031 & Nursery 2 & Leaves and shoots of $G$. inophloia & A & Negative \\
\hline 032 & Nursery 2 & Leaves and shoots of G. inophloia & A & Negative \\
\hline 033 & Nursery 2 & Leaves and shoots of $G$. inophloia & B & Negative \\
\hline 034 & Nursery 2 & Leaves and shoots of G. inophloia & B & Negative \\
\hline 035 & Nursery 2 & Leaves and shoots of G. inophloia & A & Negative \\
\hline 036 & Nursery 2 & Leaves and shoots of G. inophloia & A & Negative \\
\hline 037 & Nursery 2 & Leaves and shoots of G. inophloia & B & Negative \\
\hline 038 & Nursery 2 & Leaves and shoots of $G$. inophloia & $\mathrm{C}$ & Negative \\
\hline 039 & Nursery 2 & Leaves and shoots of G. inophloia & $\mathrm{C}$ & Negative \\
\hline 040 & Nursery 2 & Leaves and shoots of $G$. inophloia & $\mathrm{C}$ & Negative \\
\hline 011 & Private residence & Leaves and shoots of Syzygium jambos & $\mathrm{C}$ & Positive \\
\hline 012 & Private residence & Leaves and shoots of S. jambos & $\mathrm{C}$ & Negative \\
\hline 013 & Private residence & Leaves and shoots of $S$. jambos & $\mathrm{B}$ & Positive \\
\hline 014 & Commercial & Leaves and shoots of Leptospermum rotundifolium & A & Positive \\
\hline 015 & Commercial & Leaves and shoots of L. rotundifolium & A & Negative \\
\hline 016 & Commercial & Leaves and shoots of Regelia velutina & A & Negative \\
\hline 017 & Commercial & Leaves and shoots of $R$. velutina & $\mathrm{C}$ & Negative \\
\hline 048 & State institution & Leaves and shoots of $S$. smithii & $\mathrm{B}$ & Negative \\
\hline 053 & State institution & Leaves and shoots of $S$. smithii & A & Negative \\
\hline 055 & State institution & Leaves and shoots of $S$. smithii & $\mathrm{B}$ & Negative \\
\hline 050 & State institution & Leaves and shoots of Hakea salicifolia & A & Negative \\
\hline 054 & State institution & Leaves and shoots of $H$. salicifolia & B & Positive \\
\hline \multirow[t]{2}{*}{$018^{z}$} & Commercial & Approximately $1 \mathrm{~m}^{2}$ of the top of Syncarpia glomulifera and & & \\
\hline & & Agonis flexuosa 'Afterdark' mulch heap (6 weeks old) & A & Positive \\
\hline
\end{tabular}

${ }^{\mathrm{w}}$ Gossia inophloia (syn. Austromyrtus inophloia); Syzygium smithii (syn. Acmena smithii); and Hakea salicifolia (syn. H. saligna), myrtle rust nonhost (family Proteaceae).

${ }^{x}$ Spore count estimates: A, 0 spores; B, $\geq 1$ but $<20$ spores; C, $>20$ but $<100$ spores; D, $>100$ but $<500$ spores; E, $>500$ but $<2,000$ spores; and F, $>2,000$ spores.

${ }^{y}$ Unknown $=$ samples were inadvertently destroyed during the DNA extraction process.

${ }^{\mathrm{z}}$ Sample was covered with a layer of soil similar to that shown in Figure 5, which interfered with visual inspections and may have caused inhibition in the PCR test. 
for both model pathogens tested. The device was able to maintain greater suction on clothing compared with the other surfaces, which might explain the relatively high number of spores recovered from clothing. Variations in the surface ornamentation of spores and the physical and chemical nature of the surfaces (i.e., porosity, hydrophobicity, and electrostatic charge), which are known to play important roles in the adherence of spores $(2,19)$, might also explain the differences in spore recovery percentages between surfaces and model pathogens.

Although the proportion of spores recovered could not be estimated in the field experiments, the results provide additional data that support the effectiveness of the device. In all instances, samples from symptomatic myrtle rust host plants produced positive PCR results. Visual inspections agreed with the PCR results, where spores were observed in all of these samples (the majority of which had many more than 100 spores). A few samples from asymptomatic myrtle rust host plants, myrtle rust nonhost plants, and inanimate objects that were located within close proximity to symptomatic myrtle rust host plants also produced positive PCR results. Visual inspections did not always agree with the PCR results for these samples, all of which had less than 100 spores.

At relatively low spore concentrations, some discrepancies between PCR results and spore count estimations are to be expected. First, the PCR testing and visual inspections were performed on different quarters of the filter membrane. Therefore, the quarter that was PCR tested may have had more or less spores than the quarter that was visually inspected. Further, we expected that it would be difficult to visually detect spores on at least a few samples, particularly those with relatively low spore numbers. This was especially the case for samples from inanimate objects because a great deal of soil and debris was often collected in addition to spores, making it very difficult to identify spores. This extraneous material might also have inhibited the PCR assay, making it less sensitive (18). In addition, the gamma irradiation treatment that the samples were subjected to prior to DNA extraction may have degraded the DNA enough to reduce the sensitivity of the PCR assay (17).

In addition to generating false negatives, false-positive results may also have arisen during PCR testing. As well as being highly sensitive and specific to the target pathogen, the triple-nested design of the PCR assay makes it prone to cross-contamination, which increases the rate of false positives. Although we cannot discount this explanation, all internal controls included in the DNA extraction and PCR stages produced negative results, indicating that the positive PCR results are genuine (M. Glen, unpublished).
False-positive results may have arisen during the field sampling as a result of insufficiently decontaminating the device between samples. The field strategy was to sample in batches: symptomatic myrtle rust host plants (known positives) in one batch and asymptomatic myrtle rust host plants, myrtle rust nonhost plants, and inanimate objects (expected negatives) in another batch. If crosscontamination between samples did occur, it would be most evident in the first few samples between batches. This pattern, or any other pattern, is not apparent in the field results, suggesting that cross-contamination did not occur.

The objective of this study was to experimentally test the device in the laboratory and the field to generate data that evaluate its effectiveness. The results demonstrate that the device can effectively recover different types of plant pathogens from surfaces comparable with the pathways that were the subject of the project. In addition to sampling pathways, the study demonstrates that the device is particularly useful when spores from symptomatic host plants deposit on nearby host and nonhost plants, people, and inanimate objects by airborne dispersal or physical contact transfer, thereby contaminating them. The device might also be useful during the early stages of disease when infection symptoms are not visible upon gross examination. These types of contamination are likely to be missed in current surveillance for plant pathogens because inspections rely on visual identification of infection symptoms, which might not be apparent at the time of surveillance, or at all, in the case of nonhost plants, people, and inanimate objects.

The implication of failing to detect early disease on host plants is obvious but failing to detect spore contamination on inanimate objects such as clothing, vehicles, and other mobile objects is potentially more serious because disease can be spread to previously unaffected areas. This can lead to an increase in the geographic extent of diseases and makes containment, monitoring, and eradication activities considerably more difficult. The inclusion of a portable spore-sampling device in surveillance programs, together with a quick and reliable diagnostic methodology, could facilitate early disease detection in plants and contamination on surveillance personnel and objects, which might improve plant biosecurity outcomes (16). The device can also be used to gather data about the effectiveness of quarantine measures used during containment and eradication activities and, thus, provide input to risk analysis of spread mediated by such activities and support the design and testing of more effective quarantine measures.

The ability to collect spores in samples from objects on unregulated pathways - either on arrival at the receiving country or,

Table 4. Details of each sample collected from inanimate objects located near symptomatic myrtle rust host plants, including the results of spore count estimates and polymerase chain reaction (PCR) tests

\begin{tabular}{|c|c|c|c|c|}
\hline Sample ID & $\begin{array}{l}\text { Type of infected } \\
\text { premises }\end{array}$ & Description of sample & $\begin{array}{l}\text { Spore count } \\
\text { estimate }^{y}\end{array}$ & $\begin{array}{l}\text { PCR } \\
\text { result }\end{array}$ \\
\hline $019^{\mathrm{z}}$ & Commercial & $\begin{array}{l}\text { Outer surface of clothing worn underneath disposable overalls (arms, shoulders, } \\
\text { collar, cuffs of shirt; pockets, front and back of lower legs, cuffs of trousers) }\end{array}$ & A & Positive \\
\hline $020^{\mathrm{z}}$ & Commercial & $\begin{array}{l}\text { Outer surface of clothing worn underneath disposable overalls (arms, shoulders, } \\
\text { collar, cuffs of shirt; pockets, front and back of lower legs, cuffs of trousers) }\end{array}$ & A & Negative \\
\hline $043^{\mathrm{z}}$ & Nursery 2 & $\begin{array}{l}\text { Outer surface of clothing worn underneath disposable overalls (arms, shoulders, } \\
\text { collar, cuffs of shirt; pockets, front and back of lower legs, cuffs of trousers) }\end{array}$ & B & Negative \\
\hline $060^{\mathrm{z}}$ & State institution & $\begin{array}{l}\text { Outer surface of clothing worn underneath disposable overalls (arms, shoulders, } \\
\text { collar, cuffs of shirt; pockets, front and back of lower legs, cuffs of trousers) }\end{array}$ & B & Negative \\
\hline 041 & Nursery 2 & Outer surface of disposable overalls (arms, shoulders, legs, head, cuffs) & $\mathrm{C}$ & Positive \\
\hline 042 & Nursery 2 & Outer surface of disposable overalls (arms, shoulders, legs, head, cuffs) & $\mathrm{C}$ & Positive \\
\hline 056 & State institution & Outer surface of disposable overalls (arms, shoulders, legs, head, cuffs) & B & Negative \\
\hline 057 & State institution & Outer surface of disposable overalls (arms, shoulders, legs, head, cuffs) & B & Negative \\
\hline $049^{\mathrm{z}}$ & State institution & Doormat located near building entrance and almost directly underneath sample ID 044 & B & Negative \\
\hline 051 & State institution & Wooden pallets positioned directly underneath sample ID 046 & A & Negative \\
\hline 052 & State institution & Sandstone bricks located approximately $10 \mathrm{~m}$ north of sample ID 046 & B & Negative \\
\hline $058^{\mathrm{z}}$ & State institution & $\begin{array}{l}\text { Accessible parts of front tire and wheel arch of vehicle parked approximately } \\
4 \text { m east of sample ID } 047\end{array}$ & A & Positive \\
\hline 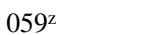 & State institution & Driver's front seat and area under steering wheel of vehicle in sample ID 058 & A & Negative \\
\hline
\end{tabular}

${ }^{\text {y }}$ Spore count estimates: A, 0 spores; $\mathrm{B}, \geq 1$ but $<20$ spores; C, $>20$ but $<100$ spores; D, $>100$ but $<500$ spores; E, $>500$ but $<2,000$ spores; and F, $>2,000$ spores.

${ }^{z}$ Sample was covered with a layer of soil similar to that shown in Figure 5, which interfered with visual inspections and may have caused inhibition in the PCR test. 
potentially, on departure in the source country-makes it possible to estimate the approach rate of contaminated objects on those pathways, and assess relative risk of entry for the pathogen. Furthermore, the ability to collect samples from surfaces that cannot be transported to a laboratory (e.g., a shipping container) makes it possible to conduct surveillance for regulated pathways and pathogens. Collectively, this information can both inform risk analysis and support decision making about the allocation of surveillance resources and the regulation of trade (26).

To supplement the data that support the outcomes of this study, we recommend further experimental work that might include evaluating the effectiveness of the device against a larger group of plant pathogens, testing more surface types to infer effectiveness on additional pathways, and investigating different types of vacuum and filter housing designs and filters.

Possible improvements to the design of the device might include the following. (i) Use of a higher-powered vacuum to improve the effectiveness of spore extraction. (ii) Use of a filter (with a larger pore size) between the vacuumed surface and the filter membrane to reduce the amount of extraneous material collected in the sample. This could improve the sensitivity of the PCR testing but may also reduce the effectiveness of spore extraction (if spores are bound up in the matrix of extraneous material). (iii) Use of an enclosed filtration vessel that can be sealed after sample collection, detached from the vacuum, and sent to the laboratory for testing without the need for handling and packaging at the sample collection location. This would reduce the likelihood of contamination of the filter membrane sample prior to receipt by the laboratory.

\section{Acknowledgments}

We thank the Department of Agriculture, Fisheries and Forestry for funding the project; E. Sheridan for sharing his early papers on passenger sampling at airports; the New South Wales Department of Industry and Investment for facilitating the field testing; M. Lindau from Murdoch University for assisting with the assembly of the spore collection device; T. Burgess, J. Cunnington, M. Hirsch, D. Letham, J. Moran, and D. Wright for their continued support and guidance throughout the project; and the two anonymous reviewers for their valuable feedback on the draft manuscript.

\section{Literature Cited}

1. Beale, R., Fairbrother, J., Inglis, A., and Trebeck, D. 2008. One biosecurity: a working partnership. The Independent Review of Australia's Quarantine and Biosecurity Arrangements: Report to the Australian Government. Canberra, Australia.

2. Braun, E. J., and Howard, R. J. 1994. Adhesion of Cochliobolus heterostrophus conidia and germlings to leaves and artificial surfaces. Experimental Mycology 18:211-220.

3. Carnegie, A. J., and Cooper, K. 2011. Emergency response to the incursion of an exotic myrtaceous rust in Australia. Australas. Plant Pathol. 40:346-359.

4. Carnegie, A. J., Glen, M., and Mohammed, C. 2010. Rapid screening of commercial forestry species to Uredo rangelii (myrtle rust) and distinguishing $U$. rangelii from Puccinia psidii (guava rust). Forests and Wood Products Australia Ltd. Report (Project No.: PRC179-0910). Melbourne, Australia.

5. Carnegie, A. J., and Lidbetter, J. R. 2012. Rapidly expanding host range for Puccinia psidii sensu lato in Australia. Australas. Plant Pathol. 41:13-29.

6. Carnegie, A. J., Lidbetter, J. R., Walker, J., Horwood, M. A., Tesoriero, L., Glen, M., and Priest, M. J. 2010. Uredo rangelii, a taxon in the guava rust complex, newly recorded on Myrtaceae in Australia. Australas. Plant Pathol. 39:463-466.

7. Chung, C., Jamann, T., Longfellow, J., and Nelson, R. 2010. Characterization and fine-mapping of a resistance locus for northern leaf blight in maize bin 8.06. Theor. Appl. Genet. 121:205-227.

8. Cook, D. C., and Fraser, R. W. 2002. Exploring the regional implications of interstate quarantine policies in Western Australia. Food Policy 27:143-157.

9. Coutinho, T. A., Wingfield, M. J., Alfenas, A. C., and Crous, P. W. 1998. Eucalyptus rust: a disease with the potential for serious international implications. Plant Dis. 82:819-825.

10. Eversmeyer, M. G., and Kramer, C. L. 1992. Local dispersal and deposition of fungal spores from a wheat canopy. Grana 31:53-59.

11. Gardes, M., and Bruns, T. D. 1993. ITS primers with enhanced specificity for basidiomycetes-application to the identification of mycorrhizae and rusts. Mol. Ecol. 2:113-118.

12. Glen, M., Alfenas, A. C., Zauza, E. A. V., Wingfield, M. J., and Mohammed, C. 2007. Puccinia psidii: a threat to the Australian environment and economy - a review. Australas. Plant Pathol. 36:1-16.
13. Grgurinovic, C. A., Walsh, D., and MacBeth, F. 2006. Eucalyptus rust caused by Puccinia psidii and the threat it poses to Australia. EPPO Bull. 36:486-489.

14. Hernández, J. R. 2006. Systematic Mycology and Microbiology Laboratory, ARS, USDA. Invasive Fungi. Puccinia psidii. http://nt.ars-grin.gov/taxa descriptions/factsheets/pdfPrintFile.cfm?thisApp=Uromycladiumtepperianum

15. Hernández, J. R. 2007. Systematic Mycology and Microbiology Laboratory, ARS, USDA. Invasive Fungi. Uromycladium tepperianum on Acacia spp. http://nt.ars-grin.gov/taxadescriptions/factsheets/pdfPrintFile.cfm?thisApp= Uromycladiumtepperianum

16. Jackson, S. L., and Bayliss, K. L. 2011. Spore traps need improvement to fulfill plant biosecurity requirements. Plant Pathol. 60:801-810.

17. Jones, L. M., Grice, K. R. E., and Davis, R. I. 2010. Gamma irradiation of dried plant material: implications for the identification of plant pathogens employing molecular techniques. Australas. Plant Pathol. 39:358-362.

18. Keswani, J., Kashon, M. L., and Chen, B. T. 2005. Evaluation of interference to conventional and real-time PCR for detection and quantification of fungi in dust. J. Environ. Monit. 7:311-318.

19. Kuo, K. C., and Hoch, H. C. 1996. Germination of Phyllosticta ampelicida pycnidiospores: prerequisite of adhesion to the substratum and the relationship of substratum wettability. Fungal Genet. Biol. 20:18-29.

20. Langrell, S. R. H., Glen, M., and Alfenas, A. C. 2008. Molecular diagnosis of Puccinia psidii (guava rust) — a quarantine threat to Australian eucalypt and Myrtaceae biodiversity. Plant Pathol. 57:687-701.

21. Loope, L., and La Rosa, A. 2008. An analysis of the risk of introduction of additional strains of the rust Puccinia psidii Winter ('ohi'a rust) to Hawai'i. U.S. Geological Survey Open File Report 2008-1008, Reston, VA.

22. McDowell, J. M., Hoff, T., Anderson, R. G., and Deegan, D. 2011. Propagation, storage, and assays with Hyaloperonospora arabidopsidis: a model oomycete pathogen of Arabidopsis. Pages 137-151 in: Plant Immunity: Methods and Protocols, Methods in Molecular Biology, vol. 712. J. M. McDowell, ed. Springer-Verlag, New York.

23. Nairn, M. E., Allen, P. G., Inglis, A. R., and Tanner, C. 1996. Australian quarantine: a shared responsibility. Department of Primary Industries and Energy, Canberra, Australia.

24. Pasche, J. S., Piche, L. M., and Gudmestad, N. C. 2005. Effect of the F129L mutation in Alternaria solani on fungicides affecting mitochondrial respiration. Plant Dis. 89:269-278.

25. Perez, C. A., Wingfield, M. J., Altier, N. A., Simeto, S., and Blanchette, R. A. 2011. Puccinia psidii infecting cultivated Eucalyptus and native myrtaceae in Uruguay. Mycol. Prog. 10:273-282.

26. Robinson, A., Burgman, M. A., and Cannon, R. 2011. Allocating surveillance resources to reduce ecological invasions: maximizing detections and information about the threat. Ecol. Appl. 21:1410-1417.

27. Seaby, D. A. 1996. Investigation of the epidemiology of green mould of mushroom (Agaricus bisporus) compost caused by Trichoderma harzianum. Plant Pathol. 45:913-923.

28. Schrader, G., and Unger, J. 2003. Plant quarantine as a measure against invasive alien species: the framework of the International Plant Protection Convention and the plant health regulations in the European Union. Biol. Invas. 5:357-364.

29. Sheridan, J. E. 1989. Quarantine risks imposed by overseas passengers. N. Z. J. For. 19:338-346.

30. Sheridan, J. E., and Nendick, D. K. 1988. II. Entry of plant pathogens into New Zealand. Victoria University of Wellington, Botany Department Report no. 25. Wellington, New Zealand.

31. Simpson, J. A., Thomas, K., and Grgurinovic, C. A. 2006. Uredinales species pathogenic on species of Myrtaceae. Australas. Plant Pathol. 35:549562.

32. Tommerup, I. C., Alfenas, A. C., and Old, K. M. 2003. Guava rust in Brazil-a threat to Eucalyptus and other Myrtaceae. N. Z. J. For. Sci. 33:420 428.

33. Viljanen-Rollinson, S. L. H., and Cromey, M. G. 2002. Pathways of entry and spread of rust pathogens: implications for New Zealand's biosecurity N. Z. Plant Prot. 55:42-48.

34. Waage, J. K., and Mumford, J. D. 2008. Agricultural biosecurity. Philos. Trans. R. Soc. 363:863-876

35. Wellings, C. R. 2007. Puccinia striiformis in Australia: a review of the incursion, evolution, and adaptation of stripe rust in the period 1979-2006 Aust. J. Agric. Res. 58:567-575.

36. Wellings, C. R., McIntosh, R. A., and Walker, J. 1987. Puccinia striiformis f. sp. tritici in Eastern Australia-possible means of entry and implications for plant quarantine. Plant Pathol. 36:239-241.

37. White, T. J., Bruns, T. D., Lee, S. B., and Taylor, J. W. 1990. Amplification and direct sequencing of fungal ribosomal RNA genes for phylogenetics. Pages 315-322 in: PCR Protocols-A Guide to Methods and Applications. M. A. Innes, D. H. Gelfand, J. J. Sninsky, and T. J. White, eds. Academic Press, New York.

38. Winter, G. 1884. Repertorium. Rabenhorstii fungi europaei et extraeuraopaei. Centuria XXXI et XXXII. Hedwigia 23:164-175

39. Zhuang, J, and Wei, S. 2011. Additional materials for the rust flora of Hainan Province, China. Mycosystema 30:853-860. 